\title{
Effect of Silicon and Seaweed Extract on Physical and Sensory Quality of Papaya cv. Red Lady
}

\author{
Dharmishtha Patel $^{1}$, T. R. Ahlawat ${ }^{2 *}$, Suchismita Jena ${ }^{2}$ and Abhijit Chaudhary ${ }^{3}$ \\ ${ }^{1}$ Department of Horticulture, Krishi Vigyan Kendra, Navsari Agricultural University, \\ Vyara, Dist. Tapi, Gujarat, India \\ ${ }^{2}$ Department of Fruit Science, ASPEE College of Horticulture and Forestry, \\ Navsari Agricultural University, Navsari, Gujarat, India \\ ${ }^{3}$ Senior Research Fellow, NAHEP-CAAST sub-project, Navsari Agricultural University, \\ Navsari, Gujarat, India \\ *Corresponding author
}

\section{A B S T R A C T}

\section{Keywords}

Silicon, Seaweed extract,

Organoleptic,

Potassium silicate,

Ortho silicic acid

Article Info

Accepted:

15 December 2019

Available Online:

20 January 2020
A field experiment was conducted at Instructional farm, ACHF, Navsari Agricultural University, Navsari, Gujarat, India to study the effect of silicon and seaweed extract on physical and sensory quality of papaya cv. Red Lady during the year 2016-17 and 2017-18. Papaya plants were sprayed with different concentrations of silicon (potassium silicate and ortho silicic acid at 0.2 and $0.4 \%$ ) and seaweed extract ( 2 and $4 \%$ ) either alone or in combinations at 3,4,5 and 6 months after planting. Application of potassium silicate@ $0.4 \%$ + seaweed extract @ $4 \%$ proved most effective in reducing physiological loss in weight and increasing shelf life with improved fruit firmness in papaya cv. Red Lady. Sensory parameters i.e. color, texture, flavor, taste, general appearance and overall acceptability were significantly better under foliar application of ortho silicic acid@ $0.2 \%$ + seaweed extract @ 2\%.

\section{Introduction}

Papaya is an evergreen, herbaceous, rapidly growing, short lived perennial tree with upright growing pattern. It is one of the economically and commercially most important fruit crop of the tropical and subtropical region. It belongs to family Caricaceae and believed to have originated from Tropical America. It is one of the most important fruit crop of Hawaii, Malaysia, Myanmar, Sri Lanka, India, Queens Land and South Africa In India, it is successfully grown all over the country and is available round the 
year. India leads the world in papaya production by virtue of producing about 6.10 million metric tonnes of papaya from an area of 0.136 million hectare with a productivity of $44.9 \mathrm{MT} / \mathrm{ha}$. In Gujarat, top five papaya producing districts are Kachchh, Tapi, Vadodara, Aravalli and Chhota Udepur (Anon., 2017). Papaya is gaining popularity due to its high nutritive value, high yielding potential, year round fruiting and multifarious uses of the plant as well as the fruit.

Papaya is sensitive to various biotic and abiotic stress which severely affect the productivity and quality of fruits. Silicon plays an important role in helping plants overcome different types of abiotic and biotic stresses. The purpose of using $\mathrm{Si}$ is to induce resistance to distinct stresses, diseases and pathogens. Silicon is prominent in cell walls as solid amorphous silica, providing a structural barrier to pathogens. Moreover, silicon minimizes toxicity of $\mathrm{Fe}, \mathrm{Al}$ and $\mathrm{Mn}$ and increases the availability of $\mathrm{P}$ and enhances drought along with salt tolerance in plants through the formation of silicified tissues in plants. Seaweed extract (SWE) being organic and biodegradable in nature is considered as an important source of nutrition for sustainable agriculture (Cassan et al., 1992).

It acts as chelated compound and soil conditioner (Norrie et al., 2002; Fornes et al., 2002 and 2005; Chouliaras et al., 2005) and is considered as an excellent natural fertilizer (Ibrahim et al., 2015) and potential biotical and pharmaceutical agents (Ito and Hori, 1989; Ahmed and Ragab, 2002).

At present, there is little information available regarding the effect of silicon and seaweed extract effect on papaya quality under South Gujarat conditions. Therefore it was deemed necessary to investigate the effect of silicon and sea weed extract on physical and sensory parameters of papaya cv. Red Lady.

\section{Materials and Methods}

The present investigation was conducted at Instructional Farm, ACHF, Navsari Agricultural University, Navsari during 2017 and 2018. Seven weeks old (15-20 cm height) papaya cv. Red Lady seedlings were transplanted at a distance of $2 \mathrm{~m} \mathrm{x} 2 \mathrm{~m}$ in the first fortnight of May. The experiment was laid out in the Randomized Block Design (RBD) with three replications and eleven treatments. The treatments were as under:

$\mathrm{T}_{1}$ : Control

$\mathrm{T}_{2}$ : Potassium silicate $0.2 \%$

$\mathrm{T}_{3}$ : Potassium silicate $0.4 \%$

$\mathrm{T}_{4}$ : Ortho silicic acid $0.2 \%$

$\mathrm{T}_{5}$ : Ortho silicic acid $0.4 \%$

$\mathrm{T}_{6}:$ Seaweed extract $2 \%$

$\mathrm{T}_{7}$ : Seaweed extract $4 \%$

$\mathrm{T}_{8}$ : Potassium silicate $0.2 \%+$ Seaweed extract $2 \%$

$\mathrm{T}_{9}$ : Potassium silicate $0.4 \%+$ Seaweed extract $4 \%$

$\mathrm{T}_{10}$ : Ortho silicic acid $0.2 \%+$ Seaweed extract $2 \%$

$\mathrm{T}_{11}$ : Ortho silicic acid $0.4 \%+$ Seaweed extract $4 \%$

Foliar sprays were done at 3, 4, 5 and 6 months after planting. Recommended dose of fertilizer 200:200:250 g NPK/plant/year was applied at 2, 4, 6 and 8 months after planting (MAP). Necessary plant protection measures were undertaken during the course of investigation. The physical parameters i.e. 
physiological loss in weight, fruit firmness and shelf life as well as sensory parameters i.e. color, texture, flavour, taste, general appearance and overall acceptability were observed during experimentation. Scoring was done by a panel of ten judges by using 9 Hedonic Scale for each character.

\section{Results and Discussion}

\section{Physical parameters}

The data regarding physical parameters of papaya fruits cv. Red Lady was recorded at eating ripe stage (Table 1). Imposition of treatments had a significant effect on physiological loss in weight, shelf life and fruit firmness in papaya fruits during both the years of investigation. Physiological loss in weight of fruits increased significantly in all treatments as the storage period progressed. The minimum loss in weight was observed in fruits subjected to treatment $\mathrm{T}_{9}$ (7.29 and 7.17 $\%)$ and it was at par with $\mathrm{T}_{11}$ (8.02 and 7.95 $\%)$ and $\mathrm{T}_{10}(8.33$ and $8.20 \%)$ during first and second year, respectively. The maximum values $\left(6.69\right.$ and $\left.6.56 \mathrm{~kg} / \mathrm{cm}^{2}\right)$ for fruit firmness were recorded in treatment $\mathrm{T}_{10}$ which was at par with $\mathrm{T}_{9}\left(6.46\right.$ and $\left.6.35 \mathrm{~kg} / \mathrm{cm}^{2}\right)$ in first and second year of study, respectively. Maximum shelf life (8.67 and 8.83 days) was registered with treatment $\mathrm{T}_{9}$ which was at par with treatment $T_{11}$ (8.33 and 8.50 days) and $\mathrm{T}_{10}$ (8.00 and 8.17 days) during 2017 and 2018, respectively. The maximum loss in weight and minimum fruit firmness and shelf life was noted in $\mathrm{T}_{1}$ (control).

Weight loss is mainly attributed to loss of water during metabolic process like respiration and transpiration. Minimum physiological loss in weight $(\%)$ in treatment $\mathrm{T}_{9}$ (PS $0.4 \%+\mathrm{SWE} 4 \%$ ) might be due to low respiration rate in potassium silicate treated fruits with $0.4 \%$ concentration and is thought to be due to reduced rate of metabolism (Stamatakis et al., 2003). These results are in agreement with those reported by Kaluwa et al., (2010) in avocado and Patil and Jagadeesh (2016) in banana with silicon. Omar and ElShemy (2008) in date palm and Omar (2014) in Washington Navel orange had earlier recorded similar results with seaweed extract.

Due to anti senescence properties and inhibition of ethylene biosynthesis, fruits treated with high concentration of potassium silicate had higher shelf life (Patil and Jagadeesh, 2016). Seaweed extracts can be an alternative to chemical fungicides for inhibiting the development of post-harvest decay, improving fruit quality and storability of fruits (Omar, 2014). Akin results were noticed by Barbang et al., (2002) in banana and Shi et al., (2012) in longan using silicon. A similar response to seaweed extract was observed in strawberry by El-Miniawy et al., (2014).

\section{Organoleptic Evaluation}

The data presented in Table 2 regarding the effect of various treatments on organoleptic evaluation for assessing the color, texture, flavor, taste, general appearance and overall acceptability of papaya fruit was done by a panel of ten judges by using 9 Hedonic Scale for each character. The color, texture, flavor, taste, general appearance and overall acceptability were significantly affected by various treatments during both the years of investigation. The best color rating (8.67 and 8.33) was recorded in $T_{10}$ during both the years and it was at par with $\mathrm{T}_{3}(8.40)$ and $\mathrm{T}_{9}$ (8.33) during 2017 and with $\mathrm{T}_{3}(8.17)$ and $\mathrm{T}_{6}$ (8.07) during 2018. The highest rating for texture (8.40 and 8.27) was given to $\mathrm{T}_{10}$ during both the years and it was at par with $\mathrm{T}_{9}$ (8.13 and 7.87) during 2017 and 2018, respectively. 
Int.J.Curr.Microbiol.App.Sci (2020) 9(1): 504-510

Table.1 Effect of silicon and seaweed extract on physical parameters of papaya cv. Red Lady

\begin{tabular}{|c|c|c|c|c|c|c|}
\hline Treatments & \multicolumn{2}{|c|}{$\begin{array}{c}\text { Physiological Loss } \\
\text { in Weight (\%) }\end{array}$} & \multicolumn{2}{c|}{$\begin{array}{c}\text { Fruit Firmness } \\
\text { (kg/cm }\end{array}$} & \multicolumn{2}{c|}{ Shelf life (days) } \\
\cline { 2 - 7 } & $\mathbf{2 0 1 7}$ & $\mathbf{2 0 1 8}$ & $\mathbf{2 0 1 7}$ & $\mathbf{2 0 1 8}$ & $\mathbf{2 0 1 7}$ & $\mathbf{2 0 1 8}$ \\
\hline $\mathbf{T}_{\mathbf{1}}$ & 9.69 & 9.58 & 2.99 & 2.83 & 5.83 & 6.00 \\
\hline $\mathbf{T}_{\mathbf{2}}$ & 9.37 & 9.12 & 3.50 & 3.44 & 6.17 & 6.33 \\
\hline $\mathbf{T}_{\mathbf{3}}$ & 8.75 & 8.69 & 3.55 & 3.47 & 6.67 & 6.83 \\
\hline $\mathbf{T}_{\mathbf{4}}$ & 8.43 & 8.32 & 5.13 & 4.96 & 7.50 & 7.83 \\
\hline $\mathbf{T}_{\mathbf{5}}$ & 8.59 & 8.48 & 4.08 & 3.95 & 7.00 & 7.17 \\
\hline $\mathbf{T}_{\mathbf{6}}$ & 8.63 & 8.52 & 4.31 & 4.22 & 6.83 & 7.00 \\
\hline $\mathbf{T}_{\mathbf{7}}$ & 8.49 & 8.40 & 5.87 & 5.73 & 7.33 & 7.67 \\
\hline $\mathbf{T}_{\mathbf{8}}$ & 8.53 & 8.41 & 5.64 & 5.52 & 7.17 & 7.50 \\
\hline $\mathbf{T}_{\mathbf{9}}$ & 7.29 & 7.17 & 6.46 & 6.35 & 8.67 & 8.83 \\
\hline $\mathbf{T}_{\mathbf{1 0}}$ & 8.33 & 8.20 & 6.69 & 6.56 & 8.00 & 8.17 \\
\hline $\mathbf{T}_{\mathbf{1 1}}$ & 8.02 & 7.95 & 4.75 & 4.54 & 8.33 & 8.50 \\
\hline $\mathbf{S E m} \mathbf{S E}$ & 0.36 & 0.36 & 0.11 & 0.10 & 0.29 & 0.27 \\
\hline $\mathbf{C D}$ & 1.05 & 1.05 & 0.34 & 0.29 & 0.84 & 0.81 \\
\hline $\mathbf{C V} \mathbf{\%}$ & 7.20 & 7.31 & 4.11 & 3.62 & 6.83 & 6.39 \\
\hline
\end{tabular}

Table.2 Effect of silicon and seaweed extract on sensory evaluation of papaya cv. Red Lady

\begin{tabular}{|c|c|c|c|c|c|c|c|c|c|c|c|c|}
\hline \multirow[t]{2}{*}{$\begin{array}{c}\text { Treatm } \\
\text { ents }\end{array}$} & \multicolumn{2}{|c|}{ Color } & \multicolumn{2}{|c|}{ Texture } & \multicolumn{2}{|c|}{ Flavor } & \multicolumn{2}{|c|}{ Taste } & \multicolumn{2}{|c|}{$\begin{array}{c}\text { General } \\
\text { appearance }\end{array}$} & \multicolumn{2}{|c|}{$\begin{array}{c}\text { Overall } \\
\text { acceptability }\end{array}$} \\
\hline & 2017 & 2018 & 2017 & 2018 & 2017 & 2018 & 2017 & 2018 & 2017 & 2018 & 2017 & 2018 \\
\hline $\mathbf{T}_{1}$ & 6.07 & 5.87 & 6.53 & 6.33 & 6.07 & 5.87 & 5.80 & 5.47 & 6.00 & 5.93 & 6.07 & 5.93 \\
\hline $\mathbf{T}_{2}$ & 6.73 & 6.53 & 7.20 & 7.07 & 6.73 & 6.60 & 6.33 & 6.20 & 6.73 & 6.60 & 6.73 & 6.60 \\
\hline $\mathbf{T}_{3}$ & 8.40 & 8.17 & 7.13 & 6.93 & 7.93 & 7.60 & 8.27 & 8.00 & 7.80 & 7.67 & 7.87 & 7.67 \\
\hline $\mathbf{T}_{4}$ & 7.20 & 7.07 & 7.40 & 7.27 & 6.93 & 6.80 & 6.73 & 6.60 & 6.93 & 6.80 & 7.07 & 6.93 \\
\hline $\mathbf{T}_{5}$ & 6.13 & 6.00 & 6.67 & 6.47 & 6.33 & 6.13 & 6.07 & 5.87 & 6.27 & 6.07 & 6.27 & 6.07 \\
\hline$T_{6}$ & 8.13 & 8.07 & 7.73 & 7.60 & 7.60 & 7.33 & 7.87 & 7.73 & 8.13 & 8.00 & 7.93 & 7.73 \\
\hline $\mathbf{T}_{7}$ & 7.67 & 7.27 & 7.67 & 7.47 & 7.40 & 7.27 & 7.80 & 7.47 & 7.70 & 7.60 & 7.60 & 7.33 \\
\hline $\mathbf{T}_{8}$ & 6.60 & 6.47 & 7.00 & 6.87 & 6.40 & 6.27 & 6.20 & 6.00 & 6.33 & 6.20 & 6.33 & 6.20 \\
\hline $\mathbf{T}_{9}$ & 8.33 & 7.80 & 8.13 & 7.87 & $8.07 \mathrm{~s}$ & 7.80 & 8.13 & 7.93 & 8.27 & 8.13 & 8.13 & 8.00 \\
\hline$T_{10}$ & 8.67 & 8.33 & 8.40 & 8.27 & 8.27 & 8.13 & 8.40 & 8.20 & 8.40 & 8.33 & 8.47 & 8.27 \\
\hline$T_{11}$ & 7.27 & 7.13 & 7.53 & 7.33 & 7.20 & 6.93 & 7.20 & 7.00 & 7.20 & 7.13 & 7.27 & 7.13 \\
\hline $\operatorname{SEm} \pm$ & 0.17 & 0.18 & 0.20 & 0.17 & 0.22 & 0.17 & 0.17 & 023 & 0.18 & 0.19 & 0.17 & 0.17 \\
\hline CD & 0.51 & 0.52 & 0.58 & 0.51 & 0.65 & 0.51 & 0.49 & 0.68 & 0.54 & 0.57 & 0.51 & 0.50 \\
\hline CV \% & 4.05 & 4.29 & 4.64 & 4.12 & 5.32 & 4.26 & 4.05 & 5.73 & 4.36 & 4.71 & 4.10 & 4.13 \\
\hline
\end{tabular}


The maximum rating for flavor (8.27 and 8.13) was given to $T_{10}$ during both years and it was at par with $\mathrm{T}_{9}(8.07)$ and $\mathrm{T}_{3}$ (7.93) during first year and with only $\mathrm{T}_{9}$ (7.80) in second year of investigation. The data regarding taste was recorded highest (8.40 and 8.20) in $\mathrm{T}_{10}$ during both the years and it was on same bar with $\mathrm{T}_{3}$ (8.27) and $\mathrm{T}_{9}$ (8.13) during first year and with $\mathrm{T}_{3}$ (8.00), $\mathrm{T}_{9}$ (7.93) and $\mathrm{T}_{6}$ (7.73) during second year of investigation. The highest rating for general appearance (8.40 and 8.33) was given to treatment $\mathrm{T}_{10}$ and it was at par with $\mathrm{T}_{9}\left(8.27\right.$ and 8.13) and $\mathrm{T}_{6}$ (8.13 and 8.00) during first and second year of study, respectively. The maximum rating for overall acceptability of fruit (8.47 and 8.27) was recorded in treatment $\mathrm{T}_{10}$, which was statistically at par with treatment $\mathrm{T}_{9}$ (8.13 and 8.00) during both the years of investigation, respectively. The minimum rating for color, texture, flavor, taste, general appearance and overall acceptability were recorded in $T_{1}$ (control) during both the years of this study.

Color change in a ripening fruit results from various physico-chemical changes that a fruit undergoes during ripening leading to characteristic appealing yellow skin color (Patil and Jagadeesh, 2016). Silicon and seaweed extract promoted sugar synthesis in fruits and thus helped in increasing Total Soluble Solids, which imparted good taste and overall acceptability to fruits (Kalatippi et al., 2016). Saeed et al., (2009) observed the role of silicon sprays in improving color and appearance of Rosa hybrid var. Hot Lady. These findings validate the results of Savvas (2009) in tomato, Tesfay et al., (2011) in avocado and Bhavya (2010) in Bangalore blue grapes.

The present investigation indicates that potassium silicate @ $0.4 \%$ + seaweed extract @ 4\% reduced physiological loss in weight, increased shelf life and resulted in better fruit firmness amongst all treatments tried.
Although, ortho silicic acid @ $0.2 \%+$ seaweed extract @ 2\% fared best in sensory evaluation it was at par with potassium silicate @ 0.4\% + seaweed extract @ 4\%. Thus, silicon and seaweed extract can be employed to improve physical and organoleptic quality of papaya cv. Red Lady.

\section{References}

Ahmed, F.F. and Ragab, M.M. 2002. A new trial to stimulate growth and nutritional status of Picual olive transplants. In: The First International Conference on Olive Cultivation, Protection and Processing, 25-27 ${ }^{\text {th }}$ September, Egypt, pp. 19-35.

Anonymous 2017. Horticultural statistics at a glance pp.148-278.

Barbang, S., Susanto, S., Novita, T., Kodir, K. and Harran, S. 2002. Studies on the physiology of polyamines and ethylene during ripening of banana and papaya fruits. Acta Horticulturae, 575: 651657.

Bhavya, H.K. 2010. Effect of foliar silicic acid and boron in Bengaluru blue grapes, M. Sc. (Hort.) Thesis, University of Agricultural Science, Bengaluru, p. 95.

Cassan, L., Jean, I., Lamaze, J. and Morotgaudry, J.F. 1992. The effect of the Ascophylum nodosum extract Geomer GA14 on the growth of spinach. Botanica Marina, 35: 437439.

Chouliaras, V., Gerascapaulos, D. and Lionakis, S. 2005. Effects of Seaweed extract on fruit growth, weight and maturation of 'Hayward' Kiwifruit. III International Symposium on Kiwifruit. Acta Horticulturae, 44: 10-20.

El-Miniawy, S.M., Ragab, M.E., Youssef, S.M. and Metwally, A.A. 2014. Influence of foliar spraying of Seaweed extract on growth, yield and quality of strawberry plants. Journal of 
Applied Science and Research, 10(2): 88-94.

Fornes, F., Sanchez-Perales, M., Guardiola, J.L. 2002. Effect of a Seaweed extract on the productivity of 'de Nules' Clementine mandarin and Navelina orange. Botanica Marina, 45(5): 486489.

Fornes, F., Sanchez-Perales, M. and Guardiola, J.L. 2005. Effect of a Seaweed extract on citrus fruit maturation. International Symposium on Quality of Fruit and Vegetable. Acta Horticulturae, 379: 200-220.

Ibrahim, H.I.M., Mansour, A.E.M. and Merwad, M.A. 2015. Impact of spraying some organic manure tea, Seaweed extract and royal jelly on fruiting of 'Keitte' mango trees. International Journal of ChemTech Research, 8(4): 2131-2141.

Ito, K. and Hori, K. 1989. Seaweed: chemical composition and potential food uses. Food Reviews International, 5: 101144.

Kalatippi, A.S., Swamy, G.S.K. and Kumbargire, G.A. 2016. Effect of diatomaceous earth on quality of pomegranate var. 'Kesar'. The Bioscan, 11(4): 2359-2362.

Kaluwa, K., Bertling, I., Bower, J.P. and Tesfay, S.Z. 2010. Silicon application effects on 'Hass' avocado fruit physiology. South African Avocado Growers' Association Year Book, 33: 44-47.

Norrie, J., Branson, T. and Keathley, P.E. 2002. Marine plant extracts impact on grape yield and quality. Acta Horticulturae, 594: 315-319.

Omar, A.E.D.K. and El-Shemy, M.A. 2008. Effect of Seaweed extracts and calcium chloride dipping on quality of Eraby date palm (Phoenix dactylifera L.) fruits during cold storage. Journal of Agricultural Research Kafrelsheikh University, 34(4): 1164-1179.

Omar, A.E.K. 2014. Use of Seaweed extract as a promising post-harvest treatment on 'Washington Navel' orange (Citrus sinensis Osbeck). Biological Agriculture and Horticulture, 30(3): 198-210.

Patil, R.M. and Jagadeesh, S.L. 2016. Effect of Silicon bunch spraying and bunch bagging on fruit yield, quality and shelf life of 'Ney Poovan' banana. HortFlora Research Spectrum, 5(3): 218-223.

Saeed, R., Babalar, M. and Siamak, K. 2009. Silicon alleviates salt stress, decreases malondial-dehyde content and affects petal color of salt stressed cut rose (Rosa hybrida L.) var. 'Hot Lady'. African Journal of Biotechnology, 8: 1502-1508.

Savvas, D. 2009. Effect of Silicon and salinity on fruit yield and quality of tomato grown hydroponically. Acta Horticulturae, 609: 141-147.

Shi, S., Wang, W., Liu, L., Shijia, W., Yongzan, W. and Weicai, L. 2012. Effect of chitosan/ nano-silica coating on the physiochemical characteristics of longan fruit under ambient temperature. Journal of Food Engineering, 118: 125-131.

Stamatakis, A., Papadantonakis, N., Simantiris, N., Kefalas, P. and Savvas, D. 2003. Effects of Silicon and salinity on fruit yield and quality tomato grown hydroponically. Acta Horticulturae, 609: 141-147.

Tesfay, S.Z., Bertling, I. and Bower, J.P. 2011. Effects of postharvest potassium silicate application on phenolics and other anti-oxidant systems aligned to avocado fruit quality. Postharvest Biology and Technology, 60(2): 92-99. 


\section{How to cite this article:}

Dharmishtha Patel, T. R. Ahlawat, Suchismita Jena and Abhijit Chaudhary. 2020. Effect of Silicon and Seaweed Extract on Physical and Sensory Quality of Papaya cv. Red Lady. Int.J.Curr.Microbiol.App.Sci. 9(01): 504-510. doi: https://doi.org/10.20546/ijcmas.2020.901.055 